\title{
Strategies to manage the evolution of glyphosate resistance in New Zealand
}

\author{
K.C. Harrington ${ }^{1}$, T.K. James ${ }^{2}$, M.D. Parker ${ }^{3}$ and H. Ghanizadeh ${ }^{1}$ \\ ${ }^{1}$ Massey University, PB 11-222, Palmerston North 4442, New Zealand \\ ${ }^{2}$ AgResearch, Ruakura Research Centre, PB 3123, Hamilton 3240, New Zealand \\ ${ }^{3}$ Foundation for Arable Research, 85 Duncan Rd, RD3, Hamilton 3283, New Zealand \\ Corresponding author: K.Harrington@massey.ac.nz
}

\begin{abstract}
The first cases of weeds developing resistance to glyphosate within New Zealand have recently been reported and investigated. Both perennial ryegrass (Lolium perenne) and Italian ryegrass (Lolium multiflorum) populations have become resistant to glyphosate in several Marlborough vineyards due to many years of weed control using mainly just glyphosate. Glyphosate is currently being used in many situations throughout New Zealand that could easily lead to further resistance developing, such as in other perennial fruit crops, on roadsides, railways, amenity areas, waste areas, fence lines and headlands of crops. Following wide consultation as part of a Sustainable Farming Fund project, strategies for resistance management in three systems (vineyard and orchards, amenity and waste areas, and crops and pastures) are suggested. Adoption of these strategies will allow glyphosate to continue as a useful herbicide in New Zealand.
\end{abstract}

Keywords Glyphosate, herbicide resistance, resistance strategy, vineyard.

\section{INTRODUCTION}

A review by Franz et al. (1997) outlines why glyphosate is the most widely used herbicide in the world. It effectively kills a very wide range of broad-leaved and grass species, both annuals and perennials. Because glyphosate translocates down into underground structures, there is usually less regrowth than with most other herbicides. It is also strongly adsorbed onto soil particles thus losing activity on contact with the soil, making it suitable for use in preparing ground for sowing crops. Glyphosate also has a lower mammalian toxicity than many other herbicides. As a result, glyphosate is widely used for weed control throughout New Zealand in areas as diverse as along roadsides, urban areas, most cropping situations and pastoral systems for crop or pasture establishment, and selectively within orchard crops and vineyards (Young 2015).

As glyphosate is generally considered more effective and environmentally more benign than most other herbicide products, it is extensively used, to the point of perhaps being over-used. There are many situations in New Zealand where glyphosate might be applied three or four times a year with no other form of weed control used, which is a recipe for herbicide resistance evolution. Glyphosate-resistant populations of weeds have developed in many parts of the world, especially in the USA and Australia (Heap 2016), due to repeated 
use of the herbicide causing selection pressure for individual plants with mutations that allow them to survive exposure to the herbicide (Preston 2015).

In 2013, the first cases of evolved glyphosate resistance were reported in New Zealand. These were perennial ryegrass (Lolium perenne) and Italian ryegrass (Lolium multiflorum). Both had developed glyphosate-resistant populations in Marlborough vineyards following many years of repeated exposure to the herbicide (Ghanizadeh et al. 2013). These discoveries indicated that it was time to develop glyphosate resistance management guidelines for New Zealand before the problem became widespread. After a number of meetings with interested parties as part of a Sustainable Farming Fund project, the following guidelines were developed, with many of the general principles based on strategies used in Australia (Preston 2015).

\section{GENERAL RESISTANCE MANAGEMENT AND PREVENTION STRATEGY}

One of the main strategies to avoid resistance from occurring is to occasionally use a herbicide with a different mode of action or to use glyphosate in combination with a herbicide with another mode of action. Plants exposed to herbicides with the same modes of action tend to develop cross-resistance, so a classification system for the modes of action for herbicides within New Zealand has been designed by the New Zealand Committee on Pesticide Resistance (NZCPR 2016) to help herbicide users to understand which herbicides have the same mode of action. Many herbicide companies display the mode of action group on the labels of their herbicides. Glyphosate is the active ingredient in a large number of products with different trade names (Young 2015), so farmers and growers alternating with other herbicides need to ensure the product is not simply another formulation of glyphosate. Although active ingredients are listed on labels, any products containing glyphosate which have the mode of action group displayed on the label will also be shown to belong to Group G. Chemical users looking to alternate their products should look for chemicals from other groups of herbicides.

Following many sequential applications of glyphosate, some people confuse the development of glyphosate-resistant populations of species that are normally susceptible to glyphosate (such as ryegrass) with the build-up of species that have never been controlled well by glyphosate, such as white clover (Trifolium repens), tall willow herb (Epilobium ciliatum) and mallows (Malva spp.) (Harrington et al. 1992). However, similar strategies are required to solve both problems, so if herbicide rotation and mixtures are used correctly, there should be no build-up of these tolerant species or individuals with genes for resistance.

As part of a good herbicide programme, observations should be made of plants not controlled by glyphosate. Poor weed control might require changes in the way herbicides are being used, rather than simply ignoring the situation. These species that have not been controlled by glyphosate should be destroyed either by hand or by the use of another herbicide. Herbicide rotations are only effective if the alternative products selected are able to control the weeds not affected by the glyphosate. Some suitable herbicide rotations will be suggested below for specific situations.

Also, it is best to apply herbicides at the recommended rates wherever possible, as applying lower rates can sometimes promote the development of resistant populations. Ghanizadeh (2015) showed that crossing resistant with susceptible plants can result in offspring with lower levels of resistance, so low application rates will allow them to survive.

Another general strategy is to not use just herbicides for weed control, but to alternate with other weed control strategies such as cultivation, mowing, growing competitive ground covers or applying mulches. Specific situations where glyphosate is currently being over-used at times within New Zealand are listed below with suggestions on how to avoid herbicide resistance from developing, both through use of other herbicides or alternative techniques. 


\section{VINEYARDS AND ORCHARDS}

Although our first cases of glyphosate resistance have developed in vineyards, similar selection pressures are probably also being applied within pipfruit orchards, kiwifruit and other perennial fruit crops. Because glyphosate is more effective and less expensive than alternative herbicides, and also less likely to result in herbicide residues within fruit which could cause market access problems like alternative herbicides, or contaminate ground-water, many growers have moved to using only glyphosate to control weeds. This has often led to a build-up of tolerant weed species such as mallows and tall willow herb.

Where possible, growers should try to rotate herbicides during and between seasons. Amitrole (Group F3) is a broad-spectrum translocated herbicide generally not permitted while fruit are on vines or trees, but can be used in late winter to clean up weeds prior to the growing season, or after fruit harvest to deal with weeds that have built-up during the season, especially perennial weeds. Unfortunately, a few (though not all) of the glyphosate-resistant ryegrass populations found in Marlborough are also resistant to amitrole (Ghanizadeh et al. 2015a).

Glufosinate (Group H) is permitted in most fruit crops and, although it doesn't translocate into root systems (Young 2015), it can be a useful product to rotate with glyphosate in summer, especially for annual weeds. In some cases weeds overseas have developed resistance to both glyphosate and glufosinate, even though glufosinate has never been used. This cross-resistance to glufosinate has also been found with all of the glyphosate-resistant ryegrass populations studied to date in New Zealand (Ghanizadeh et al. 2015a). Thus, although glufosinate is useful for controlling tolerant species such as white clover, it is probably not that useful for avoiding development of glyphosate resistance.

Paraquat (Group D) is no longer permitted by some industry bodies to be used in some fruit crops. However, this herbicide has been shown to be useful for rotating with glyphosate in fruit crops in Australia, when glyphosate resistance has caused problems, although like glufosinate it too does not move into root systems. Experience in Australian vineyards unfortunately has shown that rotating with just glyphosate and paraquat can lead to resistance to both herbicides in rigid ryegrass (Lolium rigidum) (Preston 2015).

These are the main broad-spectrum post-emergence herbicides used in fruit crops. But there are some herbicides used for specific weeds, especially Group A grass-killers such as fluazifop and clethodim which can be used for grass weeds that have not died following application of these other herbicides. Fluazifop can give good control of glyphosate-resistant Italian ryegrass but is ineffective on perennial ryegrass (Ghanizadeh 2015), which would therefore need to be treated with clethodim. Avoid overuse of Group A herbicides as resistance can develop quickly to these (Delye 2005).

Although currently discouraged by many industry quality management standards, residual herbicides can also be used to help prevent development of glyphosate resistance and thus allow more sustainable weed control. By having a herbicide such as terbuthylazine (Group C1) controlling weeds as they germinate for several months each year, this will reduce the number of weeds that need to be controlled by glyphosate. The full range of orchard residual herbicides and information on how to rotate these correctly can be found in our orchard triazine resistance strategy (Harrington 2014). Given the issues with amitrole, glufosinate and paraquat mentioned above, residual herbicides probably need to become more commonly used again in fruit crops if sustainable levels of weed control are to be maintained in coming years.

Several products exist on the market for mixing with glyphosate to improve control of tolerant species such as mallows, and these include carfentrazone, oxyfluorfen, fluroxypyr and saflufenacil. These herbicides have different modes of action to glyphosate, which may help prevent glyphosate-resistant biotypes from developing. With all of these alternatives, it is necessary to firstly check that they are registered for use in the fruit crop being considered using the Novachem 
Manual (Young 2015) or on-line sample labels for New Zealand from the chemical's proprietor.

Once trees and vines are well-established, it should be possible to have the mown sward between the crop rows growing almost up to the base of the tree or vine without affecting crop yields. With off-set mowers that can mow under the branches, herbicide really only needs to be applied for keeping vegetation away from the base of the tree or vine to facilitate the mowing process. By keeping the sprayed strip as narrow as possible, fewer weeds need to be sprayed, possibly reducing the chances of resistant individuals appearing, but also making it less costly per hectare of crop if more expensive alternative herbicides are used. If it is possible to return mown clippings on to the narrow sprayed strip, this may form a thick enough mulch to reduce the germination of new weeds. This should be avoided if plants have seed-heads, especially ryegrass which may have the resistance gene and be growing in the mown strip. Grazing of vineyards and orchards through winter may also reduce seed production for some weed species. This will not have much effect on other species such as established ryegrasses. In some systems, use of flame-weeders or shallow cultivators might be an option for controlling weeds around the base of trees and vines.

Research on a glyphosate-resistant ryegrass population from Marlborough has shown that the resistance is not exhibited when glyphosate is applied under cold conditions similar to those encountered in mid-winter (Ghanizadeh et al. 2015b). So winter spraying could remove existing resistant plants and then residual herbicides could prevent further establishment of plants as temperatures become warmer. Following work to develop quick tests for resistance (Ghanizadeh et al. 2015c), a testing service is now available from Massey University for growers wishing to test populations for resistance to glyphosate, glufosinate, amitrole or clethodim (contact authors of this paper).

\section{ROADSIDES, RAILWAYS, AMENITY AREAS AND WASTE AREAS}

Repeated and frequent use of glyphosate in situations such as roadsides, railways, urban areas and general waste areas provides a very strong selection pressure for the development of glyphosate-resistant populations of weeds. A common strategy that has been used to avoid this is to add metsulfuron to the glyphosate from time to time, or every time it is used. Using metsulfuron too frequently increases the risk of resistance developing to this herbicide too, so we recommend only adding metsulfuron once in every three or four applications. Another option is to add amitrole to the glyphosate occasionally, or to use amitrole by itself. Adding either metsulfuron or amitrole to the programme will also reduce the chance of glyphosate resistance developing.

Ideally, a residual herbicide should also be added to the mixture. This reduces the chance of glyphosate resistance developing both by reducing the regularity with which glyphosate needs to be applied plus by adding a herbicide with another mode of action to the control programme. Although residual herbicides are used less often now due to risks of contamination of water-ways, in some situations this risk may not exist. A few residual herbicides such as oxyfluorfen are less likely to leach into waterways than others. In gravelly areas such as roadsides and railways, however, residual herbicides are often less effective, providing little added benefit to glyphosate alone (T.K. James, AgResearch, unpublished data), so are mainly useful for their knockdown value.

Many residual herbicides are available on the market that might be used in waste areas, including simazine, terbuthylazine, oxyfluorfen, oxadiazon, diuron, bromacil, terbacil and imazapyr (Young 2015). Some of these are available as mixtures, such as Terminator GTA (glyphosate + terbuthylazine + amitrole) and TAG G2 (the same mixture with oxyfluorfen also added).

In some waste areas, it may be possible to make a few small changes to the site to make it more suited to being mowed, removing the need 
for herbicides and providing a better surface for reducing nutrient and hydrocarbon flow into drains than bare gravel. Or perhaps areas can be covered in concrete or bitumen to make weed growth less likely. Some areas might be suitable for converting into gardens with bark mulch and perennial shrubs to remove the need for herbicides.

\section{CROPS AND PASTURES}

Some pastoral farmers apply glyphosate frequently along the bottom of electric fence-lines to stop vegetation growing up into the fence and shorting it out. The comments above about adding in products such as metsulfuron, amitrole and a residual herbicide apply here as well. However, the best strategy may be simply to not have the bottom wire electrified or raise the bottom wire as livestock frequently graze pasture very hard under fence-lines due to less dung and urine being deposited here. Removing electrified wires at the base so that grazing is not discouraged may provide very good vegetation control, without needing to rely on non-selective herbicides which create bare ground and thus encourage weeds to establish.

Around the edges of arable crops there is usually an area of bare ground (headland) where no crop is grown so that harvesters, other machinery and crop plants do not get too close to fence-lines, especially where machinery is turning at the end of rows. Weeds generally grow in this bare soil area. Some farmers control these weeds year after year in frequently cropped paddocks using glyphosate to prevent weed seed production, contamination of the crop (e.g., by weeds such as yellow bristle grass (Setaria pumila)) and to keep paddocks tidy. If done too often, this could lead to glyphosate resistance developing. Although some of the herbicides mentioned above could be added to the glyphosate to reduce this risk, residues from these herbicides may affect future use of this land.

One possibility is to cultivate or mow the headland on occasions to keep weeds controlled. Or if the paddock was previously in pasture, the pasture could be left unsprayed and uncultivated in this zone. Recent trials by the Foundation for
Arable Research (FAR) have found establishment of weed-suppressing swards of species such as white clover, red clover (Trifolium pratense), lucerne (Medicago sativa), prairie grass (Bromus willdenowii) or other pasture grasses in this zone can decrease weed growth without relying on glyphosate (M.D. Parker, unpublished data). In addition, they provide a buffer zone for nutrient runoff, and in the case of the legumes provide additional nitrogen to the outside crop margin. These suppressive species can also be sprayed with selective herbicides to control troublesome species such as yellow bristle grass. On dairy farms in particular, these headland species can also provide extra feed when the crop stubble is grazed.

Applying glyphosate across a paddock prior to planting shouldn't result in resistance developing, even if carried out every year, because any inter-row cultivation or selective herbicides used within the crop should control any resistant individuals that survive. However, if patches of a weed survive the glyphosate spraying which would have been expected to die, cultivating the paddock prior to sowing would ensure they are controlled. Large patches of surviving weeds may not be controlled by the normal herbicides used in the crop. As the glyphosate resistance trait in ryegrasses is known to be carried in pollen (Ghanizadeh 2015), it is possible that it might spread into pastures from nearby areas where glyphosate has been overused.

\section{ACKNOWLEDGEMENTS}

Funding from the Ministry of Primary Industries through the Sustainable Farming Fund (SFF) and collaborating funding bodies, especially FAR, helped bring some of the information used in this strategy together. The assistance of colleagues within the Herbicide Resistance Task Force and also the SFF/FAR Glyphosate Resistance project in providing constructive comments on this strategy was appreciated. 


\section{REFERENCES}

Delye C 2005. Weed resistance to acetyl coenzyme A carboxylase inhibitors: an update. Weed Science 53(5): 728-746.

Franz E, Mao MK, Sikorski, JA 1997. Glyphosate: a unique global herbicide. American Chemical Society, Washington DC, USA. 653 p.

Ghanizadeh H 2015. Aspects of herbicide resistance in three New Zealand weed species. $\mathrm{PhD}$ thesis, Massey University, Palmerston North, New Zealand. 233 pp.

Ghanizadeh H, Harrington KC and James TK, 2015b. Glyphosate-resistant population of Lolium perenne loses resistance at winter temperatures. New Zealand Journal of Agricultural Research 58: 423-431.

Ghanizadeh H, Harrington KC, James TK 2015a. Glyphosate-resistant Lolium multiflorum and Lolium perenne populations from New Zealand are also resistant to glufosinate and amitrole. Crop Protection 78: 1-4.

Ghanizadeh H, Harrington KC, James TK, Woolley, DJ 2013. Confirmation of glyphosate resistance in two species of ryegrass from New Zealand vineyards. New Zealand Plant Protection 66: 89-93.
Ghanizadeh H, Harrington KC, James TK, Woolley DJ 2015c. Quick tests for detecting glyphosate-resistant Italian and perennial ryegrass. New Zealand Journal of Agricultural Research 58: 108-120.

Harrington KC 2014. Managing triazine resistance in orchards. http://resistance. nzpps.org/index.php? $\mathrm{p}=$ herbicides/triazine orchard (accessed 17 March 2016).

Harrington KC, Berry SB, Sims REH 1992. A survey of weed control practices in New Zealand pipfruit orchards. Proceedings of the $45^{\text {th }}$ New Zealand Plant Protection Conference: $285-288$.

Heap I 2016. International survey of herbicide resistant weeds. http://www.weedscience. com (accessed 16 March 2016).

NZCPR 2016. Herbicide modes of action. http://resistance.nzpps.org/index. php? $\mathrm{p}=$ herbicides/mode of action (accessed 17 March 2016).

Preston C 2015. The Australian Glyphosate Sustainability Working Group. http://www. glyphosateresistance.org.au (accessed 17 March 2016).

Young S 2015. New Zealand Novachem Agrichemical Manual. Agrimedia Ltd, Christchurch. 864 p. 